\title{
MENJAGA SEHAT, MENJAGA ADAT: PRAKTIK PENGOBATAN TRADISIONAL TUMPUROO DAN PELESTARIAN ADAT DI HUKAEA-LAEYA
}

\author{
Early Wulandari Muis ${ }^{1}$, Heksa Biopsi Puji Hastuti ${ }^{2}$ \\ ${ }^{1}$ Badan Kependudukan dan Keluarga Berencana Nasional Provinsi Sulawesi Tenggara \\ Jalan Balai Kota II No. 65, Kendari, Indonesia \\ ${ }^{2}$ Kantor Bahasa Provinsi Sulawesi Tenggara \\ Kompleks Bumi Praja, Jalan Haluoleo, Anduonohu, Poasia, Kendari, Indonesia \\ e-mail: earlywm_kdi04@gmail.com,heksa.biopsi@kemdikbud.go.id
}

\begin{abstract}
ABSTRAK
Wilayah Hukaea-Laeya ditetapkan sebagai desa adat yang dihuni oleh etnis Moronene. Orang Moronene di sini masih sangat percaya kepada tumpuroo yang berperan sebagai pengobat tradisional. Dalam hal pengobatan, bahkan sampai saat ini, masyarakat Hukaea-Laeya masih menaruh kepercayaan besar pada tumpuroo. Keberadaan tumpuroo sangat lekat dengan penjagaan kesehatan dan kebudayaan adatnya. Tulisan ini bertujuan menjelaskan praktik pengobatan tradisional oleh tumpuroo dengan berbagai nilai dan cara pandangnya, serta pengaruhnya terhadap pelestarian tradisi, khususnya mantra. Penelitian dilakukan dengan metode etnografi di Hukaea-Laeya dengan teknik pengumpulan data melalui observasi dan wawancara mendalam. Dari analisis data dapat dijelaskan bahwa tumpuroo memiliki peran strategis dalam menjaga kesehatan masyarakat Moronene dari sakit dan penyakit. Di sisi lain, mereka juga menjadi aktor penting dari upaya pelestarian kearifan lokal yang tersimpan di dalam mantra-mantra pengobatan. Terlebih ketika konsep dan pandangan hidup tentang kesehatan juga dihubungkan dengan proses menjaga adat terkait roh leluhur dan sosok transendensinya. Peran sosial kesehatan para tumpuroo ini dapat ditingkatkan oleh pemerintah untuk mendorong pemajuan dan pembangunan kesehatan berbasiskan kapasitas masyarakat lokal.
\end{abstract}

Kata kunci: Hukaea-Laeya, tumpuroo, menjaga adat, pelestarian mantra, praktik pengobatan.

\section{ABSTRACT}

The Hukaea-Laeya area has been established as a traditional village inhabited by the ethnic of Moronene. The Moronenean in this village still strongly believe in tumpuroo whose role is as a traditional healer. In terms of medical treatment, even until nowadays the people of Hukaea-Laeya still place a great trust in tumpuroo. The existence of tumpuroo is very closely related to the preservation of Moronenean traditional culture and health. This paper aimed to explain the traditional healing practices of tumpuroo with various values, perspectives, and their influence on the preservation of tradition, especially spells. The study was conducted using the ethnographic method in Hukaea-Laeya with data collection techniques through observation and in-depth interviews. From the data analysis, it could be explained that tumpuroo had a strategic role in protecting Moronenean's public health from illness and disease. On the other hand, tumpuroo also became important actors in efforts to preserve local wisdom stored in medical spells. Especially when the concept and worldview about health are also connected with the process of preserving customs related to ancestral spirits and their transcendent figures. The social health role of these tumpuroo could be enhanced by the government to encourage the promotion and development of health based on the capacity of local communities.

Keywords: Hukaea-Laeya, maintaining customs, medical treatment, spells preservation, tumpuroo

\section{A. PENDAHULUAN}

Salah satu kekayaan Indonesia adalah keragaman suku bangsa dengan budaya, dan bahasa yang unik. Mereka tersebar di berbagai wilayah daratan, lautan, pegunungan, ataupun pedalaman. Salah satu kelebihan lain adalah khazanah pengetahuan dan teknologi tradisional yang cukup kuat dalam berbagai bidang. Setiap suku bangsa memiliki pengetahuan dan keahlian tradisional dalam mengalami keterbatasan dan kerentanan dirinya masing-masing atas sakit dan penyakit. Berbekal pengetahuan leluhur tentang bahanbahan obat yang berasal dari alam, tumbuhan, dan 
hewan yang ada di sekitarnya ataupun transmisi pengetahuan lisan berupa mantra-mantra keramat turun temurun, mereka berusaha melanjutkan tradisi pengobatan itu, pun kepada para generasi pelanjutnya.

Gerungan (1987) mengemukakan bahwa manusia memiliki kebutuhan yang harus dipenuhi, salah satunya adalah kesehatan. Penyembuhan tradisional oleh dukun adalah bentuk budaya yang berkembang di masyarakat pedesaan, terlebih di masyarakat kelompok suku bangsa sehingga memengaruhi perilaku manusia dalam membuat keputusan pengobatan. Perilaku pencarian kesehatan adalah hasil dari interaksi yang kompleks dan holistik oleh individu dengan lingkungan yang memengaruhi mereka dan layanan kesehatan yang ada (Sudrajat dkk., 2016). Selanjutnya, Siregar dan Suratmin (1991) dalam penelitiannya menunjukkan bahwa masyarakat Bali lebih memilih pengobatan tradisional karena model pengobatan tradisional menggabungkan sumber biologis dengan budaya.

Sayangnya, pengetahuan dan tradisi kelompok suku bangsa dalam pengobatan ini sering kali dianggap sebelah mata oleh dunia kesehatan modern, padahal dalam upaya memajukan keberhasilan pembangunan kesehatan, kolaborasi antara pengobatan modern dan tradisional tetap perlu dilakukan. Kenyataan ini juga setara dengan mempertemukan peran pemerintah dan masyarakat dalam upaya mendorong pembangunan kesehatan yang memadai. Kobalorasi ini tentu bertujuan meningkatkan status kesehatan masyarakat, terutama mereka yang tinggal di daerah terpencil. Kolaborasi seperti ini sebenarnya telah dijamin dalam Rencana Pembangunan Jangka Panjang Nasional Indonesia (RPJPN) untuk Sektor Kesehatan 2005-2025, khususnya perwujudan pemberdayaan masyarakat untuk promosi pembangunan kesehatan.

Sekalipun jaminan regulasinya telah ada, kenyataannya hingga sekarang belum ada kolaborasi maksimal antara petugas kesehatan pemerintah dengan kelompok-kelompok masyarakat yang diyakini telah memiliki pengetahuan, keterampilan, dan keahlian dalam pengobatan. Masing-masing berdiri sendiri dan lebih menganggap bahwa praktik pengobatannya lebih andal daripada yang lainnya, walaupun saat ini telah terjadi pergeseran yang cukup kuat sehingga praktik pengobatan tradisional sering kali ditinggalkan, khususnya ketika pengobatan medis telah terbukti berhasil mengobati orang yang sakit pada suatu wilayah tertentu. Bahkan, Erasmus (dalam Lumenta, 1988) mengatakan jika perawatan medis yang dilakukan oleh obat-obatan telah berhasil menyembuhkan pasien, seringkali kepercayaan masyarakat tentang pengobatan tradisional perlahan akan beralih ke pengobatan modern.

Kenyataan seperti di atas terlihat jelas dalam berbagai kelompok suku bangsa yang memiliki kedekatan pada akses pelayanan kesehatan. Sebaliknya, bagi kelompok-kelompok suku bangsa yang jauh dari pelayanan kesehatan akan tetap bertumpu pada pengetahuan, keterampilan, dan keahlian dari sosok-sosok pengobat tradisional yang berada di lingkungan demografisnya. Fenomena seperti ini tampak jelas dalam kehidupan masyarakat Moronene di Sulawesi Tenggara.

Moronene adalah suku tertua yang hidup di semenanjung tenggara Pulau Sulawesi, Indonesia. Berdasarkan informasi dalam sastra lisan kisah Donsiolangi dan Wa Lu Ea, peradaban Moronene dimulai di daratan yang sekarang berada di wilayah Kabupaten Bombana, Kabupaten Poleang, dan Rumbia. Peradaban ini kemudian dibawa ke pulau-pulau yang berpusat di Pulau Kabaena. Sejak itu, budaya Moronene juga tumbuh dan berkembang di Pulau Kabaena. Bahasa yang digunakan oleh penduduk di Kabaena, menurut hasil penelitian, masih bahasa yang sama dengan bahasa di Poleang dan Rumbia, yaitu bahasa Moronene, tetapi keduanya memiliki dialek yang berbeda. Di daratan, Moronene memiliki wilayah adat, yaitu Hukaea-Laeya. Di desa ini, adat dan tradisi masih kuat dipertahankan, termasuk adat dan tradisi pengobatan untuk menyembuhkan sakit dan penyakit.

Hukaea-Laeya, dusun yang berada di pedalaman sabana Taman Nasional Rawa Aopa Watumohai, Bombana, menyimpan banyak keunikan. Dilintasi jalan aspal mulus tidak lantas menyeret warganya ke dalam arus modernitas. Masyarakat di Hukaea-Laeya yang ditetapkan sebagai dusun adat dihuni oleh etnis Moronene yang masih sangat memegang teguh prinsip adat dalam berke- 
hidupan. Secara administratif, Hukaea-Laeya masuk di dalam wilayah Kabupaten Bombana. Berada di pedalaman padang sabana yang diselingi hutan tropis dengan akses masuk yang cukup sulit, kampung ini seolah terpisah dari kehidupan dunia di sekitarnya. Sebagaimana umumnya penamaan tempat tradisional, HukaeaLaeya mengambil nama dari komponen alam yang berada di lokasi tersebut. Konon, nama Hukaea berasal dari nama sebuah pohon melinjo besar, sedangkan Laeya merupakan sebutan orang Moronene untuk daerah hulu Sungai Laeya, tempat mereka bercocok tanam.

Secara umum, aspek adat Moronene masih sangat kental di Hukaea-Laeya. Selain sebagai permukiman adat tertua, Hukaea-Laeya juga berpenduduk homogen, yaitu suku Moronene. Letaknya yang berada di pedalaman sabana membuatnya relatif terjaga dari arus modernitas yang ada (Hastuti \& Muis, 2016). Orang Moronene yang ada di pulau (Kabaena) dan daratan (Poleang dan Rumbia), dalam kehidupan tradisional, mereka akrab dengan praktik perdukunan. Kehadiran dukun diperlukan dalam setiap ritual tradisional Moronene, mulai dari ritual yang berkaitan dengan siklus kehidupan manusia, ritual dalam mata pencaharian, dan ritual perawatan.

Orang Moronene di Kabaena, misalnya, mengenal adanya tradisi pengobatan monttapali untuk demam. Perawatan dilakukan oleh tabib tradisional bernama sanro (Muamar, 2019). Kehadiran sanro dalam ritual monttapali adalah suatu keharusan. Sanro melakukan serangkaian tahapan ritual, yaitu tahap perawatan dengan menggunakan media medis berupa daun awarawar, koin, piring putih, dan air, serta tahap pembacaan mantra. Air sering menjadi bagian dari tradisi medis tradisional. Dalam cerita klasik, air dikatakan memiliki kemampuan memurnikan (Andaya, 2018).

Mantra dan dukun adalah dua bagian yang tidak terpisahkan satu sama lain dan harus selalu ada dalam kegiatan tradisional di Moronene. Sementara itu di daratan, terutama di HukaeaLaeya, selain sanro, orang Moronene juga mengenal mianomutuano atau tumpuroo sebagai tabib tradisional. Bahkan, tumpuroo secara resmi merupakan bagian dari struktur organisasi tradisional suku Moronene. Peran dan fungsi tumpuroo tertulis di Struktur Lembaga Adat Adati Totongano Wonua Tobu Hukaea-Laeya sebagai pemimpin berbagai upacara atau ritual tradisional.

Dalam praktiknya, bukan tidak mungkin tumpuroo juga berperan sebagai sanro karena ia memiliki pengetahuan tentang manfaat tanaman obat dan perawatan dalam sistem pengobatan tradisional Moronene. Bahkan, bisa jadi orang lebih mengenal tumpuroo sebagai herbalis daripada sanro. Seiring berjalannya waktu, tumpuroo dan sanro masih merupakan bagian penting dari masyarakat Moronene sebagai pendahulu yang menjadikan eksistensinya harus berhadapan dengan masa kini, konfigurasi baru dari aspek kehidupan, baik pribadi maupun komunal, yang secara tepat disebut sebagai "zaman baru" dalam konsep Hall dan Jacques (dalam Barker, 2006). Permasalahannya, bagaimana praktik pengobatan tradisional yang dilakukan para tumpuroo dan sanro di masyarakat adat Moronene dapat bernegosiasi dengan pengobatan medis modern yang disediakan pemerintah? Bagaimana pula mendorong mereka untuk dapat menjadi bagian penting dari promosi pembangunan kesehatan di satu sisi, dan di sisi lain tetap melakukan pelestarian atas berbagai praktik kebudayaan yang ada.

Praktik pengobatan yang dilakukan oleh dukun penyembuh tradisional seperti tumpuroo dan sanro dalam kelompok masyarakat Moronene tidak dapat dipisahkan dari eksistensi kebudayaan turun temurun di bidang kesehatan lokal. Tumpuroo di komunitas Moronene, termasuk di Hukaea-Laeya, tentu memegang peran yang cukup sentral dalam menjaga kesehatan masyarakat. Posisi tumpuroo yang dalam struktur sosialnya termasuk komponen utama dalam komunitasnya, tidak dapat dianggap sebagai penyembuh semata. Di dalamnya ada status sosial yang disandang sebagai buah dari posisi penting berdasarkan keahliannya. Penghargaan secara tradisional ini merupakan hak tumpuroo yang dapat diturunkan secara lintas generasi.

Studi tentang dukun dan praktik pengobatannya di berbagai masyarakat di Indonesia telah dilakukan oleh beberapa peneliti seperti Zulfa (2016) yang menyelidiki beberapa faktor yang memengaruhi masyarakat untuk memilih 
perawatan medis di Jorong, Batubasa, Kecamatan Pariangan, Kabupaten Tanah Datar. Faktor-faktor tersebut adalah anggaran, kebiasaan, kepercayaan, dan tradisi yang rendah. Ahyar (2017) menulis tentang makna, bentuk, dan struktur mantra sanro ana' dalam bentuk puisi lama atau puisi tradisional dalam komunitas Bugis, Kabupaten Bulukumba. Sementara Togobu (2018) menyelidiki perilaku masyarakat Karampuang terhadap praktisi medis yang dilakukan oleh dukun (ma'sanro) di Desa Tompobulu, Kabupaten Bulupoddo, Kabupaten Sinjai, Provinsi Sulawesi Selatan. Penelitian ini mengungkapkan bahwa beberapa orang memutuskan untuk pergi ke dukun ketika mereka menderita penyakit mistik (penyakit yang disebabkan oleh kekuatan alami supranatural).

Penelitian yang cukup berbeda dari beberapa penelitian sebelumnya adalah yang dilakukan oleh Humaedi (2018) pada kelompok suku bangsa Tau Taa Vana di pedalaman hutan Tojo Una-una Sulawesi Tengah. Seorang tau valia (pengobat atau dukun) memiliki fungsi sosial dan klinis. Pada fungsi sosialnya, seorang tau valia dianggap memiliki kemampuan mengetahui hukum adat atau givu ada bayar secara saksama. Hal ini terjadi karena kepercayaan tentang sakit dan penyakit dihubungkan pada ketidakseimbangan antara hukum manusia, hukum alam, dan hukum Tuhan. Ketika manusia tidak selaras menempatkan diri dalam keseimbangan tiga unsur itu, maka sakit dan penyakit akan menimpanya. Sementara dalam fungsi klinis, seorang tau valia memiliki pengetahuan, keterampilan, dan keahlian dalam meracik bahan-bahan alam dari tumbuhan, material, dan hewan untuk bahan obat. Namun, pengobatan itu tidak serta-merta bersifat herbal, tetapi juga mendorong adanya praktik pengobatan berbasiskan kekuatan spiritual. Aspek terakhir ini disebut dengan aktivitas pengobatan mobolong. Karena valia memiliki dua fungsi utama itu, mereka ditempatkan setara dengan ketua adat (tau taa ada') (Humaedi, 2018).

Berdasarkan penelitian-penelitian tersebut, praktik pengobatan dan perawatan "medis" adalah suatu kebiasaan umum pada masyarakat Indonesia. Keberadaan dukun beserta pengetahuan, keterampilan, keahlian, dan kekayaan mantra adalah khazanah praktik pengobatan yang sudah lama dikenal. Bahkan, dapat dikatakan bahwa mantra dan praktiknya tersebut telah menjadi bagian dari kesejarahan tradisi lisan nenek moyang. Salah satu bukti otentik peninggalan kebudayaan ini adalah keragaman nama yang identik dengan dukun dalam bahasa lokal di Indonesia, apalagi Indonesia memiliki lebih dari 700 etnis dengan bahasa ibu yang berbeda. Orang Jawa, misalnya, menyebut dukun atau pengobat dengan istilah dukun, sedangkan orang Moronene menamai dukun sebagai tumpuroo atau sanro.

Keragaman nama dalam bahasa lokal yang mengacu pada pemegang peran pengobat menunjukkan bahwa fenomena pengobatan tidak bisa dipisahkan dari kehidupan manusia. Seiring tumbuh dan berkembangnya manusia, pasti akan dihadapkan oleh adanya ketidakseimbangan tubuh terhadap berbagai unsur alam lainnya ataupun adanya unsur-unsur "jahat" yang masuk ke dalam tubuhnya. Ada manusia yang mati sebelum dilahirkan, ada juga yang sakit, berpenyakitan, dan bahkan meninggal, baik saat masih kanakkanak maupun saat dewasa. Untuk menghindari hal tersebut, manusia selalu berikhtiar menjaga perkembangan tubuhnya dengan baik dan sehat. Oleh karena itu, peran para pengobat menjadi sangat penting dalam kehidupan masyarakat (Foster \& Anderson, 1986).

\section{B. METODE PENELITIAN}

Tulisan ini berdasarkan data hasil penelitian etnografi yang dilakukan di masyarakat wilayah Moronene di Tobu Hukaea-Laeya. Fenomena praktik pengobatan di wilayah ini sangat menarik karena bertumpu pada kekuatan mantra di satu sisi dan keahlian peracikan obat di sisi lain. Fenomena ini persis sebagaimana temuan Humaedi (2018) di masyarakat Tau Taa Vana di Tojo Una-una. Perbedaannya terletak pada variasi tradisi pengobatan yang dikembangkan bersamaan dengan berbagai ritual yang lain. Selain itu, penelitian ini berusaha meletakkan peran tumpuroo sebagai salah satu agen penting dalam program pembangunan kesehatan di wilayah pedalaman.

Penelitian ini menggunakan metode kualitatif dengan proses pengumpulan data melalui teknik wawancara mendalam kepada beberapa orang informan yang berasal dari kelompok tumpuroo dan 
sanro, tokoh adat, dan anggota masyarakat yang dianggap mengetahui posisi dan kebiasaan praktik pengobatan ini. Data wawancara ini didukung oleh hasil amatan langsung sebagai bagian dari proses triangulasi sumber data. Mekanisme ini memungkinkan peneliti dan informan melakukan interaksi sosial secara langsung. Presentasi dan analisis data disajikan dalam bentuk deskripsi yang mendalam sehingga pembaca mendapat gambaran sedekat mungkin tentang keberadaan tumpuroo dan praktik pengobatan yang dilakukannya.

\section{HASIL DAN PEMBAHASAN}

\section{Tumpuroo dan Praktik Pengobatan Tradisional}

Hukaea-Laeya adalah tobu atau desa yang terletak di perbatasan antara Kabupaten Konawe Selatan dan Kabupaten Bombana. Hukaea-Laeya berada di pedalaman sabana yang diselingi hutan tropis dengan akses yang cukup sulit. Desa ini tampaknya terpisah dari kehidupan dunia dan modernitas di sekitarnya. Dalam "Dokumen Struktur Tradisional Adati Totongano Wonua Tobu Hukaea-Laeya dan Suluh Indonesia" disebutkan bahwa sebagai tobu tua orang Moronene di Bombana, Hukaea-Laeya dianggap sebagai wilayah Waworaha yang memiliki sejarah penting dan tidak pernah putus dengan mereka.

Keberadaan wilayah Waworaha sebagai pusat peradaban Moronene dapat dilihat terutama dari banyaknya jumlah makam leluhur suku bangsa di Hukaea-Laeya. Mereka yang sangat menghormati adat tidak bisa begitu saja melepaskan ikatan tersebut. Oleh karena itu, ketika ada kebijakan untuk memindahkan pemukim di sabana yang dikonfirmasi sebagai kawasan konservasi pada tahun 1990, mereka menolak dengan keras. Relokasi model seperti ini juga pernah terjadi pada masyarakat Dayak Sontas di Kalimantan Barat (Humaedi dkk., 2020) ataupun suku Tau Taa Vana di pedalaman hutan Tojo Una-una ke kawasan transmigrasi di dataran tinggi Bulang (Humaedi, 2018). Di dalam proses relokasi tersebut, banyak sekali upaya penolakan dari kelompok adat. Penolakan itu berdasarkan alasan-alasan, bahwa 1) mereka akan kehilangan sumber penghidupannya; 2) mereka akan meninggalkan makam- makam dan benda-benda tinggalan leluhurnya; 3) mereka akan meninggalkan berbagai kebun dan ladang yang telah dibuka secara gulir balik; 4) mereka khawatir akan ditolak dan berkonflik dengan orang-orang yang bukan berasal dari satu kelompok adatnya; dan 5) mereka khawatir tidak mampu beradaptasi dengan baik pada lingkungan dan keadaan barunya (Humaedi, 2018).

Penolakan dengan alasan seperti di atas juga dilakukan oleh orang Moronene, terlebih ketika kondisi dan latar kebudayaannya bersifat homogen. Homogenitas tersebut telah menguatkan kebersamaan mereka dalam mempertahankan sistem dan struktur adatnya, termasuk posisi tumpuroo yang menjadi bagian utama dari komponen adat di Hukaea-Laeya. Dalam konteks penolakan tersebut, tumpuroo pun tidak semata hanya mengurusi pengobatan anggota komunitas adatnya, tetapi juga ikut berperan dalam proses penolakan. Bahkan, disebut-sebut bahwa tumpuroo itu diposisikan sebagai "Dewan Penasihat" dari kepala kelompok adat. Posisi ini dapat terlihat jelas dalam bagan struktur adat yang ada pada gambar 1.

Dalam skema sistem pemerintahan desa (Gambar 1), puutobu setingkat dengan kepala desa, yang dalam struktur lembaga adat disebut juga ne e' ngkarambau'o. Sementara bonto dan limbo adalah dewan adat yang membantu puutobu memutuskan segala perkara masyarakat yang ada di dalam kampung, sedangkan tumpuroo sebagai "Dewan Penasihat" penengah dalam mendamaikan perkara yang timbul di masyarakat sesuai dengan hukum adat yang berlaku. Hubungan antara puutobu, bonto, limbo dan tumpuroo merupakan hubungan koordinasi kesepahaman penyelesaian masalah sosial kemasyarakatan.

Orang-orang yang tidak terbiasa dengan terminologi adat Moronene sering keliru dalam memahami tumpuroo dan tumpukoo. Ada perbedaan mendasar dalam fungsi yang diemban oleh tumpuroo dan tumpukoo. Tumpukoo bisa dikatakan sebagai dukun padi yang tugasnya memandu aktivitas pertanian di desa, dari awal pembukaan lahan hingga akhir saat aktivitas panen. Sementara itu, tumpuroo berada dalam peran pemeliharaan kesehatan warga atau dukun pengobatan. Supaya tidak menjadi rancu dengan 


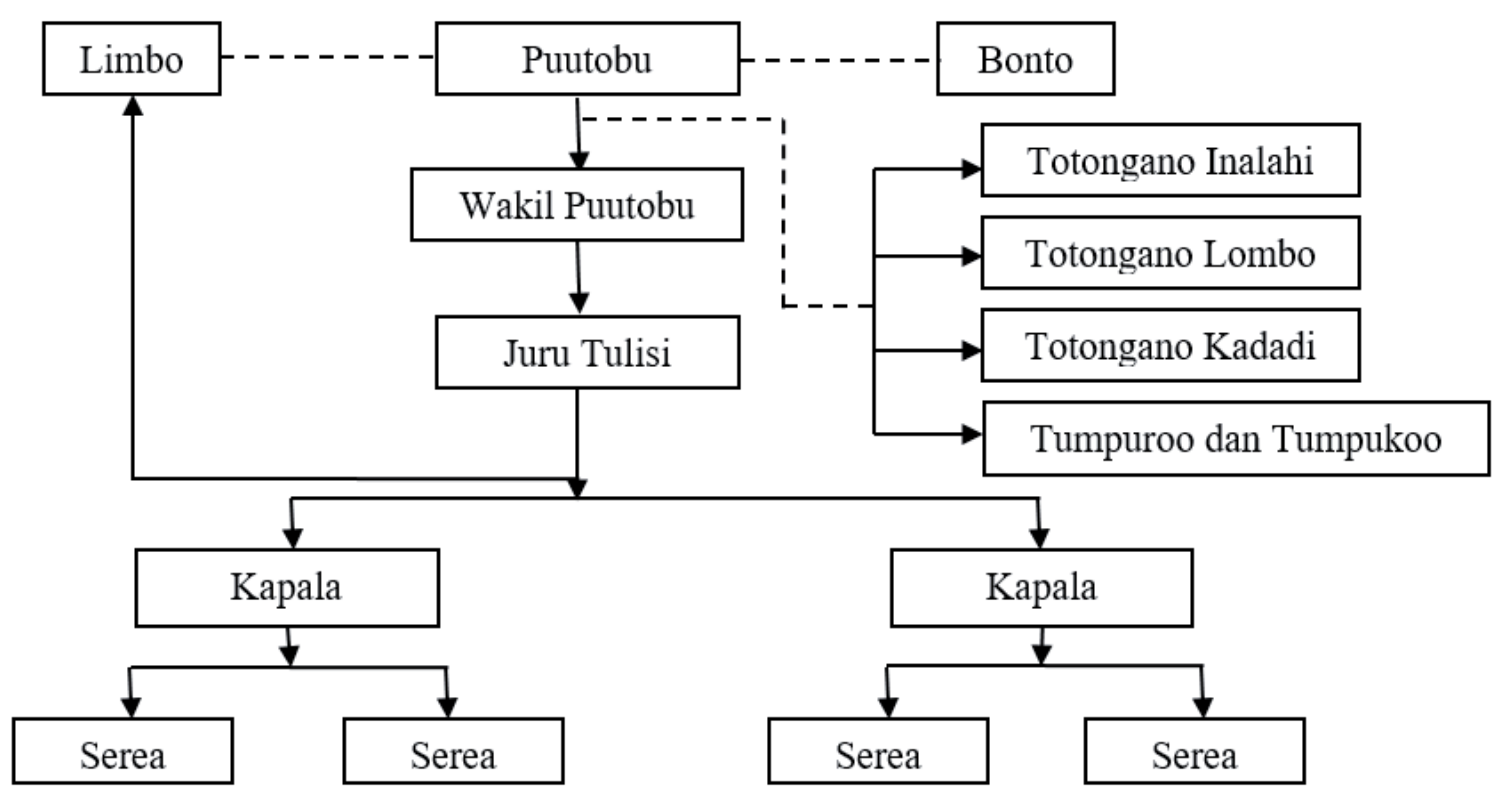

Sumber: Sturuktur Lembaga Adat Adati Totongano Wonua Tobu Hukaea-Laeya

Gambar 1. Skema Struktur Lembaga Adat Adati Totongano Wonua Tobu Hukaea-Laeya

istilah dukun (ahli), dukun yang berkenaan dengan hal mistis dalam tulisan ini disebut dengan istilah tumpuroo.

Dalam struktur perangkat adat di HukaeaLaeya yang telah terbentuk sejak zaman dahulu sebagaimana skema di atas, seorang tumpuroo dapat merangkap juga sebagai tumpukoo. Rangkap peran dan fungsi ini, misalnya, dapat dijumpai pada seorang perempuan tokoh adat di Hukaea-Laeya bernama Ina Risti atau yang lebih dikenal dengan sebutan mamanya Slamet. Ina Risti adalah satu dari sedikit orang yang memiliki keistimewaan mampu menyerap ilmu dari orang-orang tua sehingga mendapat kepercayaan menjadi tumpuroo dan tumpukoo sekaligus (wawancara dengan Ina Risti, 2018).

Dalam konteks praktik pengobatan, Ina Risti telah mewarisi keahlian dan keterampilan dari banyak orang dan tumpuroo sebelumnya. Beliau dikenal sebagai ahli pengobatan penyakitpenyakit menular dan tidak menular yang kerap diderita warga. Selain Ina Risti, di wilayah adat Moronene Hukaea-Laeya setidaknya ada dua orang tumpuroo lagi yang sudah menjalankan fungsi pengobatan sejak lama. Mereka itu adalah Pak Amin Sori dan Ina Mburi. Ketiga tumpuroo ini rata-rata mendapatkan pengaderan penge- tahuan dan keahlian dari tumpuroo sebelumnya. Namun demikian, ada beberapa kemampuan gaib para penyembuh tradisional ini yang berasal dari dasar keturunan. Pada umumnya, kekuatan gaib itu diturunkan dengan berbagai metode, seperti mimpi, pembelajaran langsung, atau semacam ritual-ritual tertentu yang dilakukan keluarganya (Astuti S. dkk. 2016).

Tiga orang tumpuroo itu dalam praktik pengobatan tradisionalnya seolah memiliki kekhususan bidang keahliannya masing-masing. Ibarat dokter spesialis, maka Pak Amin Sori, yang juga menjabat sebagai seorang puutobu di Hukaea-Laeya, disebut-sebut sebagai tumpuroo spesialis sakit yang disebabkan oleh patah tulang. Segala sesuatu yang berhubungan sakit dan penyakit terkait tulang, syaraf, dan sendi akan direkomendasikan pengobatannya ke tumpuroo satu-satunya laki-laki di Hukaea-Laeya ini. Ilmu pengobatan patah tulang yang dimiliki oleh Pak Amin Sori sebenarnya berasal dari Ina Risti. Beliau inilah yang dianggap sebagai tumpuroo paling senior. Oleh karena ada kemiripan keahlian yang sama, dalam perkembangannya, kedua tumpuroo ini akhirnya berbagi tugas. Jika ada orang laki-laki yang pata tulang, tugas Pak Amin Sori yang menanganinya terlebih dahulu. Jika 
tidak bisa, akan direkomendasikan kepada Ina Risti. Namun, jika ada perempuan yang patah tulang, rata-rata akan langsung menuju Ina Risti untuk mengobatinya.

Demikian juga dengan tumpuroo ketiga, yaitu Ina Mburi. Ia pun mendapatkan ilmu pengobatannya dari Ina Risti. Jika pada perkembangan lebih lanjut Ina Risti lebih berkonsentrasi pada penyakit menular dan patah tulang yang tidak dapat ditangani oleh Pak Amin Sori, Ina Mburi berkonsentrasi khusus pada permasalahan persalinan warga Hukaea-Laeya. Dalam posisi seperti ini, Ina Mburi berperan sebagai "dukun beranak" bagi warga masyarakat di desa itu. Hingga saat ini, seratus persen kelahiran di Hukaea-Laeya dilakukan dengan pertolongan tumpuroo. Kepercayaan warga sangat tinggi terhadap tenaga kesehatan tradisional ini. Mereka percaya bahwa Ina Mburi dapat menangani persalinan dengan baik. Sekalipun tidak mampu ditangani oleh Ina Mburi, Ina Risti akan ikut serta menanganinya dengan baik. Berbagai praktik pengobatan, baik mantra ataupun bahan alam dilakukan secara bersama-sama. Keterlibatan tumpuroo dan jaminan tumpuroo senior inilah yang membuat masyarakat merasa "nyaman" dan "aman" melakukan persalinan secara tradisional dan mandiri di kampungnya.

Setidaknya ada dua hal yang menyebabkan ketergantungan warga Moronene terhadap tumpuroo. Pertama, akses yang menghubungkan Hukaea-Laeya dengan fasilitas kesehatan modern terdekat harus ditempuh dalam waktu yang relatif lama. Sebagai catatan, Hukaea-Laeya terletak di pedalaman sabana Taman Nasional Rawa Aopa Watumohai. Dari jalan raya, jalan masuk ke dalam hanya berupa jalan setapak dan saat musim hujan dipenuhi air dan lumpur. Jadi, warga terkondisikan untuk lebih mengandalkan tenaga tumpuroo yang berada dekat dengan mereka. Hal kedua adalah masalah rasa atau perasaan nyaman bagi perempuan dan keluarga yang bersalin. Ada rasa enggan yang sangat besar dari warga, terutama ibu-ibu yang akan bersalin untuk menggunakan jasa bidan atau dokter. Keengganan itu terkait dengan tingkat kepercayaan keahlian, kemampuan penanganan, ataupun kedekatan personal yang terjalin antara satu pihak dengan pihak lainnya. Oleh karena itu, sekalipun ada tenaga medis yang ditempatkan di permukiman mereka, para ibu akan lebih suka meminta pertolongan tumpuroo daripada tenaga medis modern.

Seorang wanita hamil akan pergi ke tumpuroo secara teratur selama bulan kedelapan atau kesembilan kehamilan. Pada saat-saat itu, sang tumpuroo akan saksama dan telaten merawat wanita hamil yang akan melahirkan. Ia akan menyarankan wanita hamil tersebut untuk mandi di sungai saat dirawat. Sungai dalam konsepsi tumpuroo adalah aliran suci yang mampu membuang segala hambatan saat prosesi persalinan, walaupun bisa jadi di dalamnya ada makna agar wanita hamil tersebut melatih dirinya secara fisik untuk menyiapkan diri saat melahirkan nanti. Dengan posisi tanah berundak yang ada, wanita hamil tersebut dilatih untuk beraktivitas dengan berbagai model gerakan yang memudahkan proses pembukaan rahimnya.

Di sela-sela aktivitas dan istirahat, tumpuroo akan mulai memijat untuk memperbaiki posisi bayi di dalam rahim. Mereka pun akan meletakkan tujuh helai daun tanaman Moronene yang bentuknya masih bagus dan utuh di atas perut sang wanita hamil. Daun-daun yang ditumpuk itu kemudian dioleskan secara lembut pada perut sang wanita sebanyak tujuh kali dan digerakkan secara memutar sambil membaca doa nabi (selawat nabi). Daun tumbuhan ini diyakini dapat membuat proses kelahiran manjadi mudah, bayi menjadi bersih, dan dapat menghilangkan gumpalan darah (dalam bahasa Moronene disebut taba-taba) setelah melahirkan. Daun tersebut juga diyakini dapat membersihkan sisa-sisa darah kotor di dalam rahim ibu baru sepanjang masa nifasnya.

Ina Mburi yang dikenal sebagai tumpuroo persalinan akan berusaha menolong orang bersalin dengan menerapkan standar perlakuan yang telah dilakukan sejak turun temurun. Saat persalinan, seorang tumpuroo tidak melihat dan tidak pula memegang sama sekali kemaluan ibu yang melahirkan. Para ibu yang sedang bersalin tidak dilarang mengejan karena tumpuroo yakin bahwa keinginan mengejan secara alami akan selaras atau mengikuti irama kontraksi rahim. Pasien diminta berbaring dengan tenang dan 
keadaan tubuh bagian bawah ditutupi sarung. Tumpuroo mengarahkan dan membantu proses keluarnya bayi dengan jalan memijat bagianbagian tertentu di perut pasien. Jika kepala bayi sudah hampir keluar, maka tangan tumpuroo akan masuk ke dalam sarung untuk menadahnya. Hal ini dimaksudkan agar bayi tidak sampai terlempar di tikar atau kasur (wawancara dengan Ina Mburi, 2017).

Kepercayaan warga terhadap tumpuroo persalinan tentu didukung oleh jalinan komunikasi di antara mereka yang berlangsung secara intens. Terlebih ketika testimoni kepuasan atas kerja tumpuroo telah menyebar dari mulut ke mulut. Dalam hal ini, mereka tidak perlu mengadakan sosialisasi ataupun promosi kepada warga masyarakat lainnya. Demikian sebaliknya, warga juga akan berusaha memastikan pilihannya benar berdasarkan transmisi pengalaman dari warga lainnya. Pemilihan terhadap tenaga kesehatan tradisional dalam persalinan merupakan contoh akurat bahwa praktik pengobatan tradisional masih berperan kuat bagi masyarakat adat Moronene di Hukaea-Laeya.

Kepercayaan terhadap tumpuroo semakin menguat ketika ada banyak cerita yang diterima warga tentang model penanganan medis yang dilakukan oleh tenaga kesehatan modern. Saat membantu persalinan, seperti saat pemeriksaan dalam dan pemeriksaan pembukaan, sering kali tangan dokter atau bidan menyentuh kemaluan bahkan masuk ke dalam jalan lahir yang membuat mereka menolak untuk ditangani oleh tenaga kesehatan modern. Demikian pula informasi tentang keberadaan alat-alat tajam yang digunakan dalam persalinan oleh tenaga kesehatan modern seperti gunting dan jarum suntik pun semakin menjauhkan pilihan mereka terhadap tenaga medis modern. Para ibu Moronene merasa takut jika harus ada pengguntingan atau perobekan atas vagina mereka. Alasan-alasan tersebut cukup kuat bagi mereka dalam menentukan pilihan terhadap tumpuroo. Terlebih jika dikaitkan dengan posisi tumpuroo yang dituakan dan dianggap sebagai bagian dari keluarga besar Moronene. Dalam persoalan sentuhan atas vagina, orang Moronene memiliki kepercayaan sebagai berikut: "Saya sentuh di bawahnya, baru ketemu kepala ... Kalau mau potong pusatnya anak-anak ada juga doanya supaya tidak luka ..." (wawancara dengan Ina Mburi, 14 Oktober 2017).

Pandangan umum masyarakat Moronene tentang kemaluan, rahim, dan jalan lahir itu selalu terhubung dengan sesuatu yang transenden. Keadaan ini menuntut mereka harus menjaga kehormatannya. Oleh karena itu, siapapun yang menyentuh bagian tersebut, jika bukan bagian dari keluarga atau khususnya suami, akan menjatuhkan martabat dan kehormatan diri sang wanita. Cara pandang seperti ini sebenarnya juga dimiliki oleh berbagai kelompok masyarakat lain. Namun, karena di wilayah Hukaea-Laeya ada orang yang dituakan dan dianggap mampu membantu proses persalinan, terlebih ketika mereka pun tidak menyentuh bagian tubuh yang dianggap paling penting, masyarakat Moronene akan lebih memilih tumpuroo dibandingkan tenaga medis lainnya.

Pilihan atas tenaga persalinan di atas sering kali menimbulkan perselisihan antara tenaga persalinan tradisional dengan tenaga persalinan medis. Ina Mburi bercerita bahwa suatu ketika di dalam pertemuan tenaga kesehatan yang diprakarsai oleh Dinas Kesehatan di puskesmas, terjadi semacam konflik disebabkan oleh adanya laporan dari salah seorang bidan. Bidan tersebut melaporkan Ina Mburi melakukan kesalahan dalam operasional pertolongan persalinan saat Ina Mburi menginjak pantat pasien. Saat itu Ina Mburi tidak berhasil menjelaskan alasannya melakukan tindakan tersebut karena faktor bahasa dan komunikasi yang tidak lancar. Ina Mburi akhirnya diminta pergi meninggalkan forum pertemuan (wawancara dengan Ina Mburi, 13 Oktober 2017).

Ina Mburi kemudian menjelaskan alasan mengapa ia berani menginjak pantat pasien pada saat itu. Menurutnya, penginjakan itu sudah sesuai dengan ilmu yang diterimanya dari orang-orang tua dahulu jika menghadapi kasus persalinan bayi yang memiliki kecenderungan sungsang kaki. Tumpuroo memang harus mengupayakan pemutaran terlebih dahulu agar kepala bayi tetap berorientasi menuju jalan lahir. Bagi Ina Mburi, tindakan seperti itu telah memenuhi prosedur operasional sebagaimana ilmu dan keahlian yang 


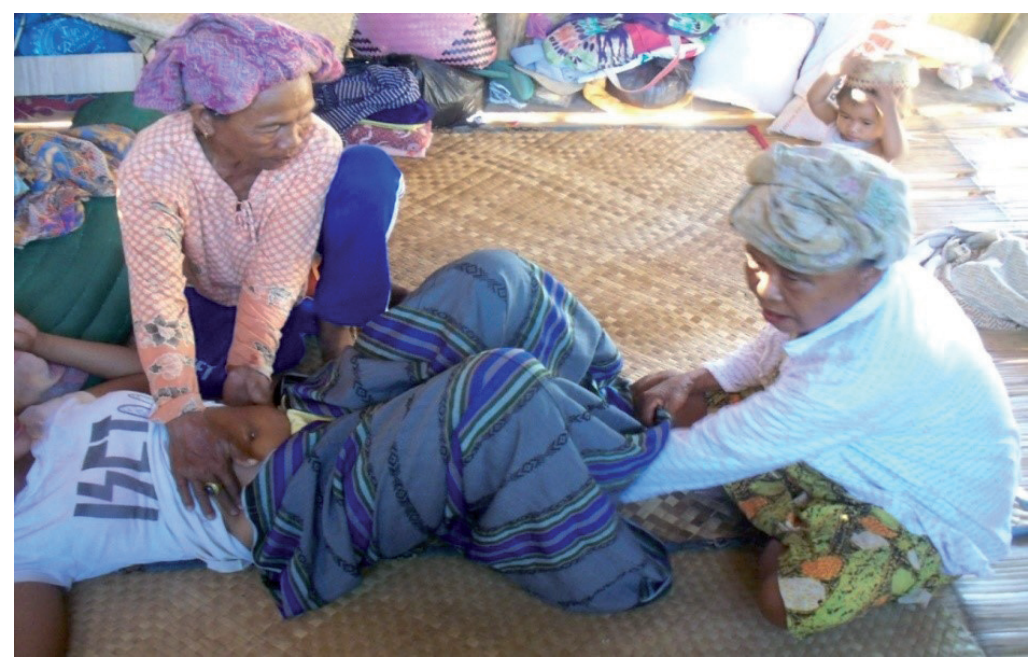

Sumber: Koleksi Pribadi Penulis (Muis, 2017)

Gambar 2. Praktik Pendampingan Persalinan Tradisional Tumpuroo Ina Mburi

diperolehnya. Sebelumnya, Ina Mburi akan membuat gulungan kain lalu meletakkannya di dubur pasien. Setelah semua dirasa aman, satu kaki Ina Mburi akan menginjak bagian pantat pasien dan satu kaki lainnya menginjak sarung. Injakan di pantat itulah yang dianggap sebagai tindakan untuk memutar posisi bayi sampai memperoleh posisi yang semestinya agar dapat segera lahir dengan baik (wawancara dengan Ina Mburi, 14 Oktober 2017).

Pada kejadian lain, seorang bidan justru meminta bantuan Ina Mburi untuk menolong kelahiran pasiennya. Sudah dua hari rahim pasien berkontraksi, tetapi bayi tidak kunjung lahir. Bidan sudah memanggil dua dukun beranak dari desa lain, namun mereka tidak banyak membantu. Di bawah pemeriksaan Ina Mburi, diketahui bahwa kepala bayi berada di dubur sang ibu, padahal seharusnya sudah lahir. Dengan metode turun-temurunnya, Ina Mburi memutar posisi bayi hingga akhirnya dapat lahir dengan selamat (wawancara dengan Ibu Haniati, 15 Oktober 2017).

Jika diperhatikan secara saksama, masyarakat Moronene lebih memilih tumpuroo dalam proses persalinannya. Mereka percaya bahwa kemampuan dan keahlian tumpuroo tidak kalah dengan tenaga kesehatan dari pendidikan formal, apalagi rata-rata tumpuroo sudah berusia lanjut sehingga telah ditempa dengan banyak pengalaman dalam menghadapi berbagai keadaan, baik normal maupun darurat. Tingkat kepercayaan seperti itu juga ditemukan oleh Fitrianti dkk. (2013). Dalam penelitiannya, ia menemukan bahwa para ibu di Desa Gayo, Kabupaten Gayo Luwes, Aceh menyatakan bahwa kepercayaan publik terhadap dukun kampung, semacam tumpuroo, sebagai rujukan kehamilan dan bantuan persalinan dipengaruhi oleh beberapa faktor. Faktor itu, misalnya 1) kekuatan pengetahuan atau mantra yang dimiliki oleh dukun kampung; 2) peran dan pengetahuan tentang ritual kampung; dan 3) jam terbang atau pengalaman dukun yang panjang dibanding dengan bidan kampung. Alasan ini semakin dikuatkan dengan pernyataan Muzaham (1995) bahwa pengambilan keputusan dan pengobatan semua komponen negatif penyakit akan dinilai berdasarkan situasi saat ini dan pengalaman masa lalu, pribadi atau tidak, dalam kehidupan kelompok sosial orang tersebut.

Lain Ina Mburi, lain pula Ina Risti yang lebih banyak menangani sakit dan penyakit yang dirasakan warga masyarakat. Orang Moronene di Hukaea-Laeya mewaspadai datangnya berbagai penyakit pada musim-musim tertentu. Sakit kalelei atau flu dan muntaber biasanya akan datang pada musim hujan. Menjelang musim penghujan, orang-orang tua sudah mulai waspada. Mereka berusaha menjaga agar anak dan keluarganya tidak terjangkit flu. Salah satu caranya dengan menghindari makanan-makanan yang dianggap dapat menjadi pemicu timbulnya penyakit tersebut. Jika di masyarakat perkotaan, es adalah 
makanan pemicu kedua penyakit tersebut, dalam kepercayaan orang Moronene, makanan seperti jambu biji merupakan makanan penyebab utama dari sakit dan penyakit yang berhubungan dengan pencernaan dan influenza.

Selain faktor alam, warga Hukaea-Laeya juga meyakini terjadinya hubungan yang tidak seimbang atau adanya hubungan paralel antara aktivitas mereka dengan kemunculan beberapa penyakit. Hubungan tidak seimbang itu, misalnya, ketika seseorang bekerja terlalu berat, sementara mereka tidak makan dalam jumlah yang sesuai, hal tersebut akan menimbulkan sakit dan penyakit. Demikian juga ketika mereka merusak sungai, berbagai penyakit terkait pencernaan juga akan muncul. Adapun terkait dengan aktivitas, misalnya saat padi mulai menguning, biasanya tidak lama kemudian banyak orang terjangkit kalelei atau influenza. Ada hubungan sebab akibat yang terangkai di sini.

Padi menguning berarti tidak lama lagi akan panen sehingga masyarakat akan melakukan aktivitas-aktivitas, seperti memotong padi, menggiling/merontokkan padi, dan sebagainya. Konsekuensi dari aktivitas-aktivitas tersebut adalah adanya persentuhan langsung petani dengan tumbuhan padi, termasuk debu/serbuk padi sebagai hasil sampingan penggilingan. Serbuk yang keluar dari mesin giling dros inilah yang menyebabkan penyakit-penyakit seperti kalelei atau influenza. Selain kalelei atau influenza, musim panen padi juga menimbulkan terjadinya musim penyakit kulit seperti kudis. Interaksi langsung dengan batang padi dan serbuk padilah yang menjadi penyebabnya. Rasa gatal yang awalnya sedikit, terus membesar menjadi bentolbentol yang kemudian terkelupas atau tergaruk dan akhirnya mengering sendiri. Masyarakat mengakui bahwa setiap tahun akan selalu terjadi musim kalelei seiring musim panen padi (wawancara dengan Ina Risti, 16 Oktober 2017). Selain padi, musim yang terjadi pada pohon buah juga dapat dijadikan sebagai penanda dari kemungkinan munculnya berbagai penyakit. Menjelang musim berbuah jambu atau mangga, misalnya, dapat menjadi tanda dari munculnya penyakit kalelei atau influenza.
Sementara itu, apabila hujan turun tidak menentu, biasanya banyak warga, terutama anak-anak, yang terkena penyakit diare disertai muntah-muntah. Terlebih saat awal musim penghujan setelah kemarau yang terik. Pada saat itulah, mereka pada umumnya akan enggan berobat ke puskesmas dan memilih mendatangi para tumpuroo. Sekalipun hanya diberikan mantra ataupun diberi ramuan yang berasal dari tumbuhan-tumbuhan sekitar, mereka percaya bahwa praktik pengobatan itu akan membuat diri dan keluarganya sembuh dari sakit dan penyakit yang dideritanya. Keyakinan atas kesembuhan ini sama persis dengan keyakinan mereka bahwa para tumpuroo secara turun-temurun dapat menduga datangnya berbagai penyakit yang ada. Mereka yakin bahwa para tumpuroo telah mahir dalam mempelajari gejala alam, aktivitas manusia, dan kaitannya dengan ancaman penyakit yang mungkin timbul (wawancara dengan Ina Risti, 16 Oktober 2017).

Terkait penyakit diare, Ina Risti mengatakan bahwa apabila seseorang sudah tiga kali buang air besar, biasanya tinja encer akan berkurang. Warga Hukaea-Laeya sendiri sebenarnya sudah mengenal pemberian larutan gula garam untuk penderita diare. Bedanya, larutan gula garam untuk penderita diare di Hukae-Laeya dibacakan mantra dan doa-doa dari tumpuroo. Keyakinan warga atas tiup-tiup tumpuroo ini sudah ada sejak lama dan menjadi semakin kuat dengan adanya beberapa kejadian di daerah ini. Pada suatu ketika, seorang warga terjangkit diare dan beberapa kali berobat ke puskesmas. Beberapa waktu lamanya pasien tersebut mengonsumsi obat dari puskesmas, tetapi tidak kunjung membaik. Dalam perjalanan menuju puskesmas untuk yang ke sekian kalinya, nyawa pasien ini tidak tertolong, dia meninggal di jalan. Sementara orang lain yang menderita penyakit yang sama lalu meminta pengobatan dari tumpuroo, dengan obat yang sama dan diberi tiup-tiup, mereka sembuh. Berdasar atas dua peristiwa ini, masyarakat semakin yakin untuk memilih pengobatan atas penyakit-penyakit tertentu kepada para tumpuroo.

Seperti yang telah dijelaskan sebelumnya, selain penyakit pada sistem pencernaan, penyakit kulit juga kerap diderita oleh warga Hukaea- 
Laeya. Sama dengan kalelei atau influenza, penyakit kulit juga datang ketika musim panen padi. Penyebabnya pun sama, yaitu debu dari penggilingan padi, terlebih jika padi yang ditanam menggunakan pupuk dan obat-obatan kimia. Orang-orang yang bekerja di sawah lebih rentan terkena penyakit ini. Warga biasanya membiarkan penyakit ini jika pekerjaan memanen belum selesai. Begitu musim panen berlalu dan pekerjaan menggiling padi selesai, mereka akan mendatangi para tumpuroo atau menunggu sekian waktu agar penyakit kulitnya sembuh dengan sendirinya. Namun jika belum sembuh, mereka pun akan mendatangi para tumpuroo.

Praktik pengobatan yang dilakukan oleh Ina Risti juga diiringi dengan penggunaan beberapa resep ramuan yang diracik sendiri. Racikan ini diperoleh dari transmisi pengetahuan dan keterampilan pengobatan yang diterima oleh tumpuroo sebelumnya sehingga dipercayai akan memberikan kesembuhan atas sakit dan penyakit yang diderita pasiennya. Beberapa resep pengobatan itu dapat dijelaskan sebagai berikut.

1. Obat penyakit lambung atau mag, ramuan obatnya terdiri atas:

a. tiga lembar daun komba-komba dimakan setiap pagi,

b. tiga buah pisang bugis mentah atau yang tidak kecut dibuat kolak dan dimakan setiap pagi.

2. Obat untuk luka adalah kayu jawa dan daun komba-komba.

3. Obat untuk kalelei atau flu dan muntaber/ diare yang disertai muntah adalah daun jambu biji muda. Warga akan diobati oleh tumpuroo dengan cara meniupkan daun jambu biji muda. Tujuh lembar daun jambu biji dibacakan selawat, lalu dimakan dengan sebutir garam kasar. Ada juga alternatif obat berupa tumbuhan berbentuk tali menjalar sebagai obat diare.

4. Penyakit kudis diobati dengan kulit kayu pohon wilalo yang dikerok lalu diperas dan digosokkan ke kudis. Penyakit kudis juga bisa disembuhkan dangan menggunakan kulit tumbuhan perdu yang biasa disebut tumbuhan nene (resam/clinogyne grandis benth). Kulit nene diambil lalu dipukul-pukul supaya hancur, kemudian diremas sampai keluar airnya. Air kulit nene dibalurkan ke kudis atau dapat juga untuk penyakit kulit lainnya.

5. Penyakit untuk kulit kepala atau rambut seperti gatal-gatal karena koreng, ketombe, rambut putih (uban), bengkak-bengkak/ bisul dan pusing bisa diobati menggunakan wilalo juga (wawancara dengan Ina Risti, 17 Oktober 2017).

Pembagian penyakit antara berat dan ringan berdasar pada pengalaman yang pernah terjadi di Hukaea-Laeya, diare termasuk penyakit yang dianggap berat karena kalau terlambat ditangani bisa menyebabkan kematian. Informasi tentang pengobatan modern sudah mereka terima, baik melalui sosialisasi dinas kesehatan maupun dari para pemuda yang memiliki mobilitas cukup tinggi sehingga dapat mengakses informasi dari luar. Meski demikian, pilihan berobat kepada tumpuroo masih tetap menjadi yang utama bagi warga Hukaea-Laeya. Pilihan terhadap pengobatan tradisional ke tumpuroo sebenarnya tidak sekadar berdasar pada konteks kecocokan ataupun keadaan yang jauh dari pusat pelayanan kesehatan. Pilihan ini terkait erat dengan worldview masyarakat tentang sakit dan penyakit, tentang dunia sekitarnya, dan ikatan kosmologis dalam jaringan kekerabatan yang terbentuk secara turun-temurun. Dalam konteks ini, tumpuroo adalah bagian penting dari keluarga yang memberikan rasa aman dan nyaman serta melakukan hal terbaik dalam mengatasi segala keterbatasan anggota keluarga lainnya. Ikatan kosmologis, worldview, dan keadaan geografis tersebut menjadi faktor utama dari praktik pengobatan tradisional tumpuroo beserta seluruh unsur di dalamnya-pengetahuan, keahlian meracik obat alam, dan penggunaan mantra-mantra pengobatan-yang akan tetap lestari dan hidup di tengah-tengah masyarakat Hukae-Laeya. Tiga faktor praktik pengobatan tradisional itu menjadi fenomena umum berbagai kelompok masyarakat adat di nusantara (Humaedi, 2018). 


\section{Tumpuroo dan Pelestarian Mantra di Hukaea-Laeya}

Pengobatan tradsional yang dilakukan oleh tumpuroo, selain memanfaatkan kekayaan alam berupa obat-obatan herbal dan ritual-ritual tertentu, juga pada umumnya selalu disertai dengan bacaan mantra. Dalam konteks lokal, mantra itu disebut dengan istilah baca-baca. Baca-baca ini diturunkan dari para leluhur yang dalam perjalanannya mengalami perubahan sesuai dengan dinamika yang ada. Misalnya, masuknya Islam di kalangan masyarakat Moronene berpengaruh juga pada bacaan yang dituturkan ketika tumpuroo mengobati pasiennya. Doa-doa, baca-baca, atau mantra ini biasanya dituturkan lalu diikuti dengan tindakan meniupkannya ke obat ramuan yang telah disiapkan atau ke arah bagian tubuh pasien yang sakit. Berkenaan dengan kebiasaan ini, mantra yang dibacakan biasa juga disebut dengan istilah tiup-tiup.

Sebagai komponen budaya tradisional, mantra masuk ke wilayah cerita rakyat, khususnya sebagai bagian dari tradisi lisan. Danandjaja (1986) mengklasifikasikan mantra sebagai puisi rakyat. Bentuk wicara biasanya berupa garis atau larik sehingga termasuk dalam genre puisi (puisi lama). Idealnya, sastra lama, termasuk genre puisi, berfungsi sebagai identitas budaya yang harus melekat pada komunitas. Ratna (2011) menggarisbawahi bahwa literatur lama tidak boleh dilupakan, tetapi harus dipromosikan dengan makna baru. Mempertahankan keberadaan mantra di tengah-tengah modernitas juga berarti menjaga keberadaan puisi lama menjadi kekayaan yang tak ternilai karena di dalamnya tersimpan kearifan lokal dan pengetahuan bagi pemilik kelompok. Kekayaan lokal ini akan selalu berkelanjutan jika kondisi sosial dan budaya cukup kondusif (Herawati, 2015).

Sebagai komponen kebudayaan tradisional, mantra masuk ke dalam wilayah folklor, khususnya sebagai bagian dari tradisi lisan. Bentuk tuturan yang biasanya berupa baris-baris atau larik membuatnya termasuk dalam genre puisi (puisi lama). Menjaga eksistensi mantra berarti juga menjaga eksistensi puisi lama yang menjadi kekayaan tidak ternilai bagi kelompok pemiliknya.

Tumpuroo juga dapat berperan sebagai dukun budaya yang memimpin upacara ritual di wilayahnya, misalnya ritual mo'oli. Ritual tradisional mo'oli biasanya dilakukan oleh orang Moronene di Tobu Hukaea-Laeya sebagai bentuk penghormatan terhadap penguasa alam (ntiwonua). Meskipun penguasa tidak terlihat, $n t i-$ жопиа diyakini sebagai representasi roh leluhur. Ntiwonua masih dihormati dan meminta izin untuk acara yang akan diadakan. Dalam setiap upacara adat Mo'oli akan selalu membutuhkan kehadiran tumpuroo. Kehadiran tumpuroo untuk menyiapkan ritual disertai dengan sesaji dan mantra seperti yang ditunjukkan pada Gambar 2 dan 3. Ritual ini dilakukan dengan melafalkan mantra dan menyajikan persembahan dengan aturan yang disepakati selama beberapa generasi.

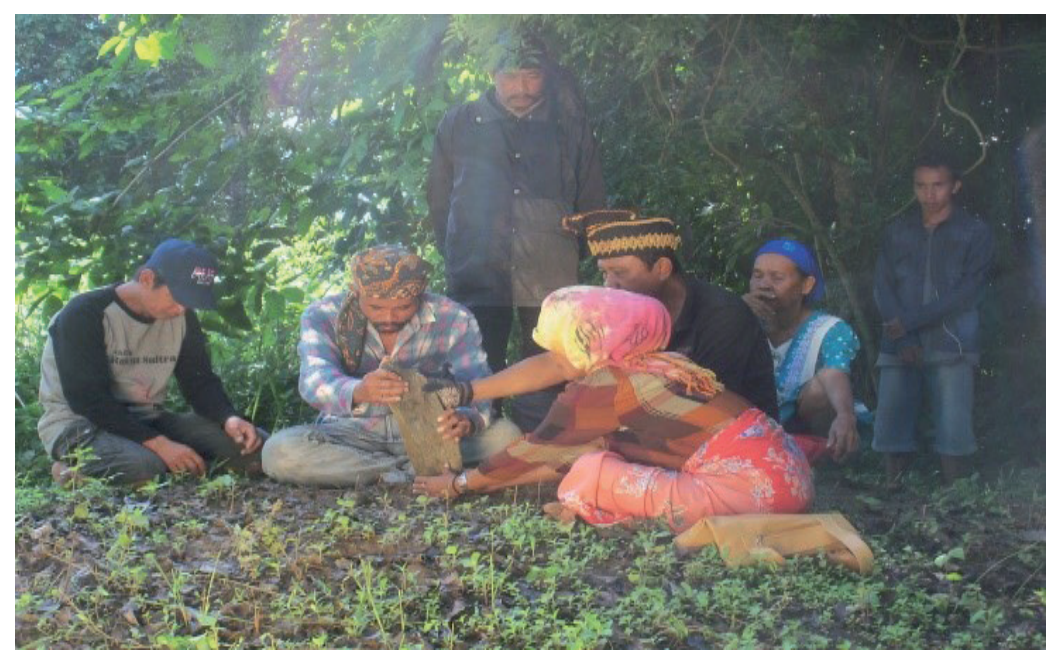

Gambar 3. Tumpuroo (perempuan) meminta izin kepada leluhur untuk melakukan persembahan ritual mo'oli. 


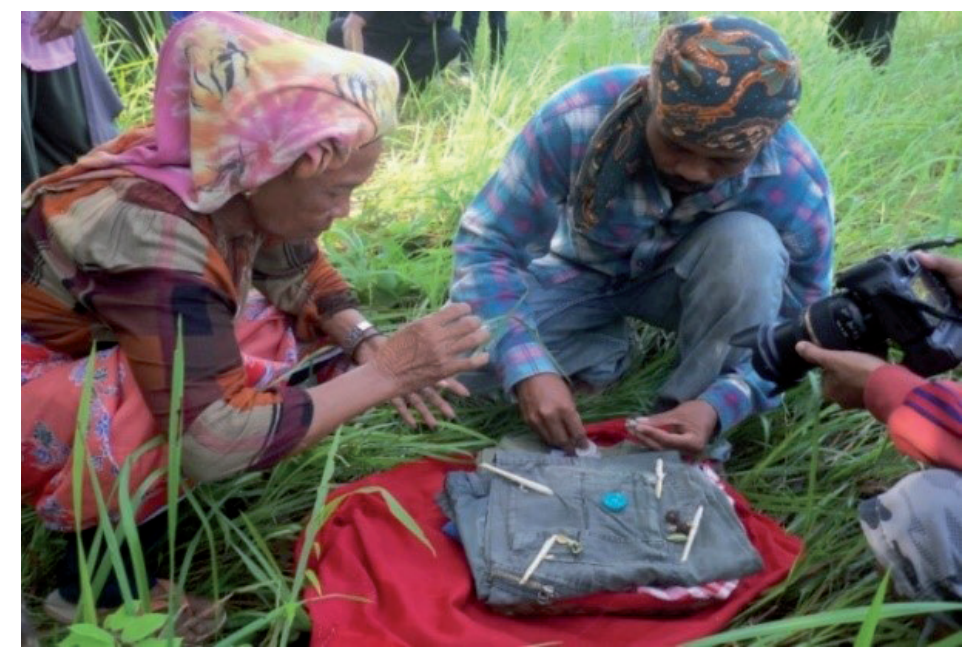

Gambar 4. Tumpuroo (perempuan) menyiapkan persembahan untuk ritual mo'oli.

Saat ritual tersebut, beberapa mantra akan dibacakan oleh tumpuroo. Terdengar jelas di dalamnya ada mantra panjang dan mantra yang sangat pendek. Pilihan atas jenis-jenis mantra itu tentu berdasarkan konteks kegiatannya ataupun harapan yang hendak dicapai oleh pelaksana ritual. Salah satu bait mantra dalam ritual mo'oli memiliki makna yang menyiratkan adanya sebuah hubungan antara kuasa yang transenden dengan manusia pelaku ritual. Di dalamnya, sarat dengan konsepsi tentang dia yang memberi dan dia yang menerima (berkat dan sesaji). Ritual mo'oli juga tidak sekadar upacara penghormatan dari manusia kepada dia yang transenden, tetapi juga ada bentuk penghargaan dari generasi sekarang kepada para leluhur pada masa lalu.
Bagi mereka, orang-orang tua pada masa generasi terdahulu-direpresentasikan oleh para penguasa (sangia)-telah memberikan berkah serta perlindungan kepada generasi masa sekarang dan mereka pun pantas menerima imbalan dari generasi sekarang. Salah satu bentuk penghargaan itu adalah sesaji dan mantra yang mengingatkan jasa-jasa mereka. Dalam konteks ini, melestarikan adat dengan berbagai ritualnya berarti menghormati keberadaan dan jasa-jasa leluhur. Generasi masa sekarang yang masih hidup telah menerima berkah serta perlindungan dari para penguasa (sangia) atau roh leluhur dan mereka pun memiliki kewajiban memberikan imbalan berupa pelestarian adat dalam berbagai bentuk upacara adat.

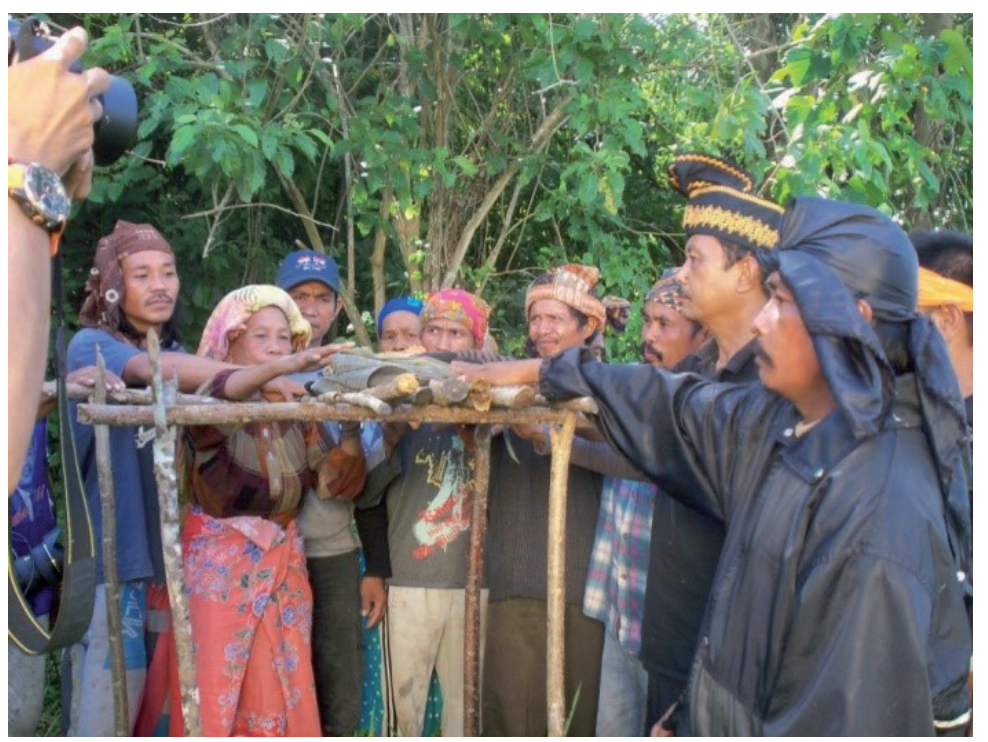

Keterangan: Tumpuroo (wanita dengan sarung merah) memimpin ritual mo'oli dan membaca mantra.

Gambar 5. Pelaksanaan Ritual Mo'oli, Bentuk Penghargaan Kepada Leluhur 
Dalam ritual mo'oli, beberapa mantra pun akan terucap seiring dengan urutan pelaksanaan upacaranya. Prosesi terakhir upacara tersebut adalah ketika para undangan yang berasal dari semua warga masyarakat yang hadir memegang sesaji yang dipersembahkan kepada ntiwonua. Semua warga berusaha memegang sesaji itu untuk menunjukkan diri bahwa ia hadir, terlibat, percaya, menghormati, dan ikut memberikan hadiah yang disukai para roh leluhurnya. Keterlibatan mereka adalah bukti penghormatan mereka atas leluhur. Pada saat semua memegang sesaji itu, tumpuroo akan membaca mantra sebagai berikut.

Oooo ... asa orua otolu opaa
Oooo ... asa orua otolu opaa

Somba komiu sangia da tungkuo daa paraiho

Saluwuluwumiu cumiu pera ro sangia

Die kaasi kusie Kusie tekeke baakoako lako hai cumiu

Hi kuda mowango adati

Kami sireako komeo pera ha ano mo sao

Oooo .... satu dua tiga empat

Oooo .... satu dua tiga empat

Mohon maaf wahai sangia yang menempati yang membawahi

Ini kasihan jangan saya mendapat teguran dari kita

Sementara saya membangun adat

Singkirkan segala malapetaka

Ada lima aspek penting dalam mantra di atas, yaitu 1) sangia, sebagai leluhur; 2) saya, para pemberi sesaji; 3) teguran, sesuatu yang mengingatkan; 4) membangun (menjaga) adat; dan 5) malapetaka. Kelima aspek di atas ratarata terkandung dalam berbagai mantra yang diucapkan oleh tumpuroo pada upacara yang bersifat kolektif. Dalam pandangan mereka, lima aspek itu saling terhubung, terikat bersama, dan menjadi faktor penentu dari "keamanan ataupun kegagalan" individu dan warga masyarakat secara umum. Kata "aman" menunjukkan pada kesejahteraan secara sosial, ekonomi, psikis, dan kesehatan. Di dalamnya ada konsepsi tentang kekayaan, kesuburan, kesehatan badan dan psikis yang memadai, dan kebahagiaan individu, keluarga, dan warga masyarakat.

Keadaan tersebut terjadi jika sangia sebagai roh leluhur dan ntiwonua sebagai kekuatan transenden tetap dihargai dan diingat oleh seseorang (individu dan kolektif). Mereka harus melakukan secara rutin atau setiap ada keinginan tertentu berdasarkan inisiatifnya sebelum adanya teguran dari kedua unsur yang dikeramatkan itu. Teguran yang dimaksud bisa berupa gagal panen atau kesehatan yang buruk. Mereka percaya penghormatan kepada sangia dan ntiwonua juga harus diwujudkan pada upaya melestarikan adat. Kata pelestarian adat terdiri atas penjagaan sistem kekerabatan dan keturunan, kepatuhan atas berbagai aturan atau norma adat, penggunaan bahasa ibu Moronene, dan penjagaan hak-hak wilayah. Jika hal ini tidak dilakukan oleh masyarakat Moronene di HukeaLaeya, akan menyebabkan terjadinya malapetaka.

Ada berbagai bentuk malapetaka yang diyakini oleh masyarakat, misalnya 1) kekeringan sepanjang tahun terus menerus yang menyebabkan kesuburan tanah dan pasokan air akan sangat berkurang; 2) kegagalan panen sehingga masyarakat akan mengalami kelaparan, terjadi penurunan kesejahteraan, dan jatuh miskin; 3) merebaknya wabah penyakit sehingga banyak warga masyarakat yang mengalami sakit dan penyakit; 4) hancurnya sumber daya alam atau kelestarian lingkungan yang menyebabkan masyarakat tidak mendapatkan kenyamanan hidup; dan 5) hancurnya tatanan sosial masyarakat sehingga konflik dan perkelahian akan sering terjadi.

Dalam konteks malapetaka inilah, sakit dan penyakit dianggap sebagai salah satu unsur penting dari keengganan masyarakat untuk menghargai sangia dan ntiwonua. Jika ditarik lurus, sakit dan penyakit yang ada diyakini sebagai bagian dari ketidakseimbangan manusia dalam memosisikan diri di tengah jasa para roh leluhur dan berkat dari Sang Transenden yang dipercayainya. Mereka yang tidak menjaga atau melestarikan adat yang di dalamnya terkandung makna "tidak hormat kepada sangia dan ntiwonua" adalah sosok-sosok yang memiliki potensi kuat terkena sakit dan penyakit.

Sayangnya, sakit dan penyakit tersebut tidak akan selalu bersifat individual, tetapi akan menjadi wabah yang dialami oleh semua orang. Dalam konsep adat, hal ini menjadi pengingat manakala ada warga desa yang tidak menghormati adat. Prinsip kebersamaan dan kohesi sosial akhirnya 
menjadi bangunan utama dalam menjauhkan masyarakat dari sakit dan penyakit. Karena sakit dan penyakit itu terhubung dengan ikatan kosmologis dari "menjaga adat", orang yang berwenang mengobatinya pun akan dianggap sebagai bagian terpenting dari struktur adat. Hal yang wajar jika akhirnya para tumpuroo kemudian mendapatkan posisi terhormat di masyarakat Moronene. Alasan lainnya adalah tumpuroo dianggap sebagai pihak perantara paling penting untuk mengajukan permohonan maaf kepada sangia dan ntiwonua atas keteledoran seseorang untuk menjaga adat. Selain itu, mereka juga dianggap sebagai pihak yang memperantarai bentuk penghargaan atau berbagai keinginan masyarakat terhadap sangia dan ntiwonua sehingga kehidupannya menjadi aman, sejahtera, bahagia, dan sehat, baik secara fisik, psikis, sosial, dan ekonomi.

Keberadaan tumpuroo di Hukaea-Laeya sangat vital dalam upaya pelestarian budaya, terutama pelestarian mantra. Selain melakukan peran dan fungsi dalam aspek kesehatan (pengobatan), tumpuroo juga mengemban peran dan fungsi sebagai penjaga kelestarian budayanya. Generasi muda yang semakin meninggalkan kebudayaan berbau lokal sesungguhnya menjadi tantangan tersendiri bagi pemerintah. Peran tumpuroo dalam konteks ini akhirnya dapat memperkuat pelaksanaan UU terkait bahasa dan budaya nasional dan daerah. Dalam Undang-Undang Republik Indonesia Nomor 24 Tahun 2009 Pasal 42 telah diatur bahwa pemerintah daerah berkewajiban secara aktif melakukan upaya pelestarian bahasa dan sastra daerah, termasuk di dalamnya adalah puisi lama (mantra), agar tetap memenuhi kedudukan dan fungsinya dalam kehidupan bermasyarakat sesuai dengan perkembangan zaman dan menjadi bagian dari kekayaan budaya Indonesia.

Sebagai amanat undang-undang negara, tidak berlebihan apabila ada solusi untuk mendamaikan posisi dan peran tumpuroo dengan kemajuan peradaban manusia, baik dalam aspek budaya maupun kesehatan. Dari aspek pengobatan, tumpuroo, misalnya, perlu diberi edukasi terkait kebersihan peralatan dan tempat yang digunakan selama praktik pengobatan tradisionalnya berlangsung. Selain itu, tumpuroo juga bisa diberi peran sebagai duta sanitasi ataupun agen promosi kesehatan di masyarakat dengan menggunakan perspektif dan pandangan hidup (worldview) masyarakat Moronene. Posisi tumpuroo yang dihormati dan didengar kata-katanya oleh warga akan dapat menjanjikan hasil yang lebih optimal dalam menyampaikan pesan-pesan dari dinas kesehatan daripada disampaikan langsung oleh petugas dinas. Dengan demikian, pemajuan dan pembangunan kesehatan berbasiskan komunitas dapat terlaksana dengan baik, intensif, dan berdampak langsung di masyarakat.

\section{PENUTUP}

Praktik pengobatan tradisional di berbagai komunitas suku bangsa di Indonesia tetap menarik untuk diangkat dan dimaknai. Di dalamnya, tidak hanya berhubungan dengan upaya mengatasi sakit dan penyakit dalam arti realitas, tetapi juga terhubung dengan berbagai ikhtiar terkait penjagaan keseimbangan atas manusia dengan Tuhannya, manusia dengan alamnya, dan manusia dengan manusia lainnya. Konsepsi sakit dan penyakit yang ada kemudian tidak sesederhana karena rusaknya fungsi tubuh atau keadaan tidak baik yang dialami oleh seseorang, tetapi juga karena pengalaman dan perilaku individu dan kolektif dalam menjaga ikatan kosmologis dari unsur yang disucikan.

Konsepsi praktik pengobatan tradisional seperti yang dijelaskan sebelumnya pun dilakukan oleh masyarakat Moronene di Hukaea-Laeya, Sulawesi Tenggara. Dengan keterbatasan akses terhadap pelayanan kesehatan dari pemerintah, para tumpuroo sebagai tenaga kesehatan lokal yang memiliki legitimasi sosial dan spiritualitas berusaha melayani warga masyarakatnya dengan baik. Mereka berusaha memadukan antara pengetahuan dan keahlian teknik fisik, peracikan obat dari bahan-bahan alam yang ada di sekitarnya, dan kemampuan memperantarai manusia dengan sangia dan ntiwonua dengan berbagai mantra. Para tumpuroo tersebut terbukti mampu mengurangi beban masyarakat saat prosesi persalinan, pengobatan sakit dan penyakit (dari sakit ringan, patah tulang, sampai sakit dalam dan sakit berat), dan memberikan rasa nyaman bagi kehidupan masyarakatnya. Masyarakat pun meyakini bahwa para tumpuroo ini adalah aktor paling penting 
dalam menjauhkan masyarakat dari berbagai jenis malapetaka, termasuk di dalamnya wabah penyakit. Ikatan kosmologis yang mampu mempertemukan permintaan maaf, pemberian, dan keinginan masyarakat kepada sangia dan ntiwonua ketika memimpin upacara ritual mo'oli dengan berbagai mantra dan sesajinya adalah bukti bahwa mereka adalah sosok penting dalam struktur sosial masyarakatnya.

Aspek strategis tumpuroo dalam praktik pengobatan tradisional sebenarnya dapat dimanfaatkan untuk kepentingan pembangunan kesehatan yang diharapkan pemerintah. Para tumpuroo dapat dilibatkan untuk mendorong promosi kesehatan, pola hidup sehat dan bersih, serta keluarga sejahtera ke masyarakat luas. Dalam prosesnya, tentu tidak boleh mengindahkan edukasi-edukasi sistem kesehatan modern terlebih dahulu, khususnya dalam hal kebersihan dan sanitasinya. Dari sisi pemerintah, juga tidak boleh memaksakan cara pandang yang berbeda dengan konsepsi dan praktik pengobatan tradisional yang selama ini dilakukan oleh tumpuroo. Dengan memberdayakan tumpuroo menjadi mitra pemerintah (dinas kesehatan), dua keuntungan dapat dicapai, yaitu kualitas kesehatan masyarakat semakin membaik di satu sisi dan di sisi lain kekayaan budaya dan sastra daerah pun dapat dilestarikan dengan baik. Keadaan ini sangat mungkin tercapai karena konsepsi dan pandangan hidup masyarakat Moronene juga selalu menghubungkan penyebab sakit dan penyakit dengan pelanggaran adat. Artinya, dengan menjaga dan melestarikan adat (seperti bahasa, budaya, dan adat tradisinya), kesehatan masyarakat juga akan terjaga. Dalam konteks ini, pembangunan kesehatan berbasis kapasitas masyarakat lokal akan benar-benar tercapai.

\section{DAFTAR PUSTAKA}

Ahyar F., F. (2017)._Mantra dukun beranak dalam persalinan tradisional masyarakat Bugis di Kabupaten Bulukumba: Kajian antropolinguistik_[Tesis]. Universitas Hasanuddin, Makassar.

Andaya, L.Y. (2018). Water in the study of Southeast Asia. Kemanusiaan, 25, 21-38. https://doi. org/10.21315/kajh2018.25.s1.2.
Astuti, S., Sulaiman, H., \& Astuti, W.D. (2016). Perempuan Banjar dalam dekapan penyakit "kelalah": Etnik Banjar, Kabupaten Banjar. Unesa University Press.

Barker, C. (2006). Cultural studies teori dan praktik. Kreasi Wacana.

Danandjaja, J. (1986). Folklor Indonesia. Grafitipers.

Fitrianti, Y., Ichwansyah, F., \& Pratiwi, N.L. (2013). Peran dukun Kampung Gayo dalam kesehatan ibu. Dalam Tri Juni Angkasawati, Lestari Handayani, \& Agung Dwi Laksono (Eds.), Simpang jalan pelayanan kesehatan ibu dan anak (13-30). Kanisius.

Foster, G.M., \& Anderson, B.G. (1986). Antropologi kesehatan. Grafiti.

Gerungan, W.A. (1987). Psikologi sosial. Eresco.

Hastuti, H.B.P., \& Muis, E.W. (2016). Syair mo'odulele sebagai strategi lokal dalam membentuk pola hidup bersih dan sehat di Tobu Hukaea-Laeya: Sebuah wacana. Dalam S. S. F. A. Hanan (Ed.), _Prosiding Seminar Nasional Pemberdayaan Bahasa dan Sastra Daerah Sulawesi Tenggara dalam Membangun Karakter Masyarakat Multikultur_, 185-194.

Herawati. (2015). Identitas kultural dan karakteristik lisan orang kaili dalam mantra tamabunto. Kandai, 11(2), 161-175.

Humaedi, M.A. (2018). Etnografi pengobatan: praktik pengobatan dan sugesti masyarakat adat Tau Taa Vana di pedalaman hutan Tojo Una-Una. LKiS

Humaedi, M.A., Setiawan, B., Patji, A.R., Sudiyono, \& Sukmawati, A.D. (2020). Bahasa dan budaya dayak sontas bagi persatuan bangsa. LIPI Press.

Lumenta, B. (1988). Penyakit, citra alam dan budaya. Kanisius.

Muamar. (2019)._Pengobatan tradisional monttapali pada suku Moronene di Kecamatan Kabaena Selatan Kabupaten Bombana_ [Skripsi]. Universitas Halu Oleo, Kendari.

Muzaham, F. (Ed.) (1995). Memperkenalkan sosiologi kesehatan. UI Press.

Ratna, N.K. (2011). Antropologi sastra. Pustaka Pelajar.

Siregar, H.R.J. \& Suratmin. (1991). Pengobatan tradisional pada masyarakat Bali. Yogyakarta: Kanisius.

Sudrajat, A., Soerachman, R., \& Fahriani, A. (2016). Surga dukun 'Mama biang'di Negeri Poilaten etnik Talaud-Kab. Kepulauan Talaud. Surabaya: Unesa University Press. 
Menjaga Sehat, Menjaga Adat: Praktik Pengobatan Tradisional Tumpuroo dan Pelestarian Adat di Hukaea-Laeya

Togobu, D.M. (2018). Gambaran perilaku masyarakat adat Karampuang dalam mencari pengobatan dukun (ma'sanro). J-KESMAS: Jurnal Kesehatan Masyarakat, 4(1) 16-32.
Zulfa, V. (2016). Penyebab masyarakat memilih melakukan pengobatan ke dukun (studi kasus di Kenegerian Batubasa, Jorong, Kecamatan Pariangan, Kabupaten Tanah Datar). STKIP PGRI Sumatera Barat. 